\title{
Say Goodbye to Mildew and Save Energy Home Study Course - Part III: Mildew "Hot" Spots - Techniques to Reduce Moisture ${ }^{1}$
}

Virginia Peart ${ }^{2}$

Running air conditioning continually to eliminate mildew problems, without controlling moisture, requires a lot of electric energy. As power production costs continue to rise, electrical utility bills rise. To save energy, to save money, to avoid the work of mildew clean-up and potential mildew allergy problems, people want to prevent mildew problems. If they already have mildew problems they would like to stop them and keep mildew from spreading. Prevention of mildew in warm, humid climates requires an understanding of mildew, what makes it grow and spread, and what can be done to control the situation.

There are many types of mildew, but what makes mildew grow is pretty much the same for every type. The conditions that promote or stop mildew growth are the same in all parts of the country or anywhere in Florida. Part I of this home study course was designed to help you understand what mildew is and what makes it grow.
Part II was designed to help you understand why humidity is often high in Florida homes. Part III gives you ideas for how you can protect your Florida home from mildew and other moisture related problems.

\section{Mildew Hot Spots}

How can you keep your home dry enough to avoid mildew problems?

So far you have learned that outside air in Florida is very humid and ventilation will not remove excess moisture most of the time. Let's look at the three mildew havens in homes: Bathrooms, Closets and Bedrooms. Some research being done at the University of Florida indicates that although mildew can and does occur in almost every room in a house, three locations are the worst: bathroom, closets and bedrooms. Moist indoor air not only encourages mildew growth, but is uncomfortable and increases energy use.

1. This document is FCS 3213, one of a series of the Department of Family, Youth and Community Sciences, Florida Cooperative Extension Service, Institute of Food and Agricultural Sciences, University of Florida. Publication date: September 2002. First published in December 1990 by the Florida Energy Extension Service. Reviewed: September 2002 Please visit the EDIS Web site at http://edis.ifas.ufl.edu

2. Written by Virginia Peart, former Associate Professor, Housing, Department of Family, Youth and Community Sciences, Cooperative Extension Service, Institute of Food and Agricultural Sciences, University of Florida, Gainesville, 32611 and reviewed by Nayda I. Torres, Professor, Family and Consumer Economics, Department of Family, Youth and Community Sciences, Cooperative Extension Service, Institute of Food and Agricultural Sciences, University of Florida and Dale Dorman, Extension Housing and Environment Specialist - Emeritus, Cooperative Extension Service, University of Georgia. 


\section{Bathrooms}

What can be done to cut down on mildew cleaning chores in a bathroom?

- Of course it is important to keep bathrooms clean, but even a tiny bit of soap or body oils from showering will support mildew growth so it is also important to keep bathrooms dry.

- Cooler showers put less moisture into the air and take less energy to heat the water.

- Get water into the drain. Some people have reported they keep a window squeegee in their shower and take a minute or two after showers to wipe water into the drain.

- If you are battling a serious mildew problem you may want to carry wet towels to a rack in the garage or on the porch to dry.

- Turn on your exhaust fan as soon as you start to shower and allow it to run for about 10 to 15 minutes after you finish. (But turn it off after that to keep from bringing too much outside air into the rest of the house.)

- Open a window to bring in air only if outside air is dry. Otherwise it's best to allow the bathroom exhaust fan to pull conditioned air from other rooms of the house.

- As an extra precaution, you may want to turn on your air conditioner for about 10 minutes immediately after showering. This may be very helpful during mild, but humid weather, when neither heating nor air conditioning is being used.

\section{Closets}

Moisture migrates into closets much more easily than it can come out naturally. Anything damp you put into a closet can add to the moisture problem -- even a little moisture in shoes or other clothing.

- For a closet in the bath area, keep the door closed when shower moisture is present.

- Louvered doors encourage closet air movement and will keep a closet drier. Keep solid closet doors open (except when you have visitors) if the closet has a musty smell.

- Open shelving (plastic coated wire) allows air circulation.

- Keep items off the floor. Moisture can be trapped under them.

- Add a source of heat. A low wattage light bulb, placed far enough from clothing, or anything that will ignite, will raise the temperature in a closet and reduce the relative humidity. A low location is best because hot air rises.

- Desiccants, materials like calcium chloride that absorb moisture, are of little use in a closet since the space to be dehumidified is large compared to the moisture holding capacity of such materials, if the rest of the house is humid.

\section{Bedrooms}

Many Florida homes have mildew occurring in the bedroom areas. People like to sleep with their windows open. When humidity is high, which is most of the year, too much moisture can come in. Additional moisture is produced by people while they are sleeping. How can moisture problems in this part of a house be reduced?

- Don't bring in outside air, unless it is dry enough. Dewpoint or nighttime temperature should be $60^{\circ} \mathrm{F}$ or lower. 
- Air must be circulated in the bedroom -- the bedroom door should be left ajar at night, if there is no return air duct in the room or if neither air conditioning nor heat is being used.

\section{Chemical Mildew Inhibitors}

Should you use a chemical mildew inhibitor? Products containing paraformaldehyde are "toxic" to both mildew and people. They should not be used in spaces when people are there. Always read the label of products before you buy them. Make sure they are safe. Always follow label precautions and directions.

\section{Removing Mildew}

How do you remove mildew, if you find it? On washable, bleachable items, chlorine bleach can be used. Other cleaning agents include detergent, denatured alcohol, non-chlorine bleach such as sodium perborate or potassium monopersulfate, and trisodium phosphate.

\section{Which Cleaning Agent?}

Which cleaning agent to use and how it can be used will depend upon the characteristics of the material to be cleaned: Is it safe to get it wet or will it shrink or stretch or swell? Will the chemical used react in any way with the material that will cause discoloration, fading, or other damage? Are there related problems, such as hard water, which will, for instance, make keeping tile and bathroom fixtures difficult to keep clean?

Because cleaning methods for mildew vary greatly among different types of items and materials, specific cleaning agents, methods of cleaning, and precautions must be followed. Check with the publication FCS 3042, How to Prevent and Remove Mildew.

\section{Clean and Dry}

If you want to avoid mildew and other moisture related problems, keep your home both DRY and CLEAN. By controlling the climate in your home, you can save energy while avoiding mildew and other moisture-related problems.

\section{Test Your Knowledge}

See the quiz to test your knowledge. 


\section{QUIZ}

\section{Mildew "Hot" Spots: Techniques to Reduce Moisture}

\section{Circle Your Answer}

True or False

$\mathrm{T}$

$\mathrm{T}$

$\mathrm{T}$

$\mathrm{T}$

$\mathrm{T}$

$\mathrm{T}$
$\mathrm{F}$

$\mathrm{F}$

F

F

F

$\mathrm{F}$

1. The mildew hot spots in most Florida homes are bathrooms, closets, and bedrooms.

2. It is very rare to have mildew in bedrooms.

3. One of the reasons Florida homes have mildew in their bathrooms is because people don't open bathroom windows to air the room out after bathing or showering.

4. A light bulb left on in a closet helps prevent mildew there, not because of the light bulb but because of the heat.

5. To avoid mildew problems, it's a good idea to open windows and doors to ventilate your home at night when the temperature drops below $75^{\circ} \mathrm{F}$.

6. Chemical mildew inhibitors are safe to use regularly to stop mildew growth. 